\title{
The Impact of Processing Methods on Chemical Composition, Mineral Bioavailability and Functional Properties of Nigerian-Grown Cashew Flour
}

\author{
Makinde Folasade Maria ${ }^{a^{*}}$ And Joel Ifeoluwa HannaH ${ }^{\mathrm{a}}$ \\ ${ }^{a}$ Department of Food Science and Technology, Bowen University, Iwo, Osun State, Nigeria \\ ${ }^{*}$ Corresponding author \\ sademakin@yahoo.com \\ TEL: +2348072673097
}

Received: 23 October 2017; Published online: 18 April 2019

\begin{abstract}
In this study, the effect of processing methods on the nutritional quality and functional properties of cashew (Anacardium occidentale Linn) kernels were investigated. The kernels were soaked, autoclaved, roasted or germinated at varying time duration; raw kernel served as control. The samples were analysed for chemical, mineral bioavailability and functional properties. Data was subjected to analysis of variance and means were separated by the Duncan multiple range test. The result of chemical composition analyses revealed that raw cashew kernels contained $3.55 \pm 0.08 \%$ moisture, $21.3 \pm 0.05 \%$ protein, $45.0 \pm 0.15 \%$ fat, $2.53 \pm 0.02 \%$ fibre, $1.59 \pm 0.02 \%$ ash, $26.1 \pm 0.01 \%$ carbohydrate, $521.75 \mathrm{Kcal} / \mathrm{g}$ energy, $2210.09 \pm 0.02 \mathrm{mg} / \mathrm{kg}$ calcium, $1712.54 \pm 0.03 \mathrm{mg} / \mathrm{kg}$ magnesium, $60.04 \pm 0.01 \mathrm{mg} / \mathrm{kg}$ iron and $36.74 \pm 0.02 \mathrm{mg} / \mathrm{kg}$ zinc. Tannin, phytate and oxalate concentrations in the raw cashew kernel were $10.14 \pm 0.03 \mathrm{mg} / \mathrm{kg}, 99.30 \pm 0.02 \mathrm{mg} / \mathrm{kg}$ and $11.03 \pm 0.03 \mathrm{mg} / \mathrm{kg}$ respectively. Increased fat, ash and fibre levels were noted for treated samples compared to raw kernels. Mineral concentrations were increased significantly by various treatments compared to raw kernel; however, germination resulted in the highest increase of mineral content. A reduction trend was observed in phytate, oxalate and tannin concentrations in the treated samples with respect to increased processing time. Consequently, various treatments influenced the bioavailability of mineral elements. Treated samples exhibited significant differences in loose and packed bulk densities, water and oil absorption capacities when compared to raw kernels. Germination shows potential to generate not only much needed nutrients in cashew for human development, but also improved bioavailability of nutrients and functionality compared to other processing methods. This approach can used in Community Nutrition and Emergency Feeding Programmes, in developing countries, where the consequence of anti-nutritional factors may worsen the incidence of malnutrition and disease.
\end{abstract}

Keywords: Cashew; Nutrient; Mineral bioavailability; Functionality; Processing effects

\section{Introduction}

The nutritional inadequacies in developing countries that arise from high cost of animal proteins have necessitated the use of other protein food sources such as those from plant origins. Tree nuts such as almonds, cashews, hazel nuts, macadamias, pecans, pine nuts, pistachios and walnuts are readily available and offer great potential as a ready to eat food for human consumption.

The cashew tree (Anacardium occidentale Linn) is a native of Brazil and widely cultivated across the coastal regions of the tropics (Gibbon \& 
2 | Maria and Hannah

Pain, 1985). The major producing countries of the cashew nut are Tanzania, India, Mozambique, Srilanka, Kenya, Madagascar, Thailand, Malaysia, Indonesia, Nigeria, Senegal, Malawi and Angola. Cashew was introduced into Nigeria in $16^{\text {th }}$ century; however, the cultivation has spread to western, eastern and northern states (Hammed, Anikwe, \& Adedeji, 2008). It is important to note that cashew nut is underutilized in Nigeria as only about $10 \%$ is utilized locally (FAO, 2008).

The cashew fruit is made up of the apple in which the kernel is embedded. The kernel has high nutrient value and consists of $21.2 \%$ protein, $22.0 \%$ carbohydrate and $47.0 \%$ fat; it offers $575 \mathrm{kcal}$ of energy per $100 \mathrm{~g}$ and various minerals (Sathe, 1994). As with other tropical nuts, the cashew comes with associated issues such as the presence of secondary plant metabolites that are also known as anti-nutritional factors (ANFs). These include tannin, phytate and trypsin inhibitor which bind with minerals such as Fe, Zn and other similar metals, and protein respectively. These metabolites subsequently interfere with nutrient utilization when fed to human (Ngatchic et al., 2013).This activity remains a major drawback to the direct use of cashew as food ingredient. Several processing techniques have been reported by various investigators that may enhance the nutritional quality of food materials and also reduce or destroy the anti-nutrient present in them (Esenwah \& Ikenebomeh, 2008; Słupski, 2011). The knowledge of how processing conditions modify bioavailability of nutrients trapped in the food matrix is indeed a critical factor to be considered in the development of food for various age groups in addition to cost of raw ingredients, processing cost and sensory acceptability of such foods (Abebe, Stoecker, Hinds, \& Gates, 2006). Similarly, the functional performance of plantbased protein is also important in determining its usefulness in food systems. This study adds to the current knowledge of cashew nutrition and reports the effect of soaking, autoclaving, roasting or germination on the nutritional quality and functional properties of cashew flour.

\section{Materials and Methods}

\subsection{Materials}

Cashew nuts were purchased from a local market in Kogi State, Nigeria. All chemicals used were of analytical grade and were purchased from Sigma Chemical Company, St. Louis, MO, USA.

\subsection{Preparation of cashew flour}

Cashew nuts were sun dried to facilitate shelling. The dried nuts were shelled manually with the use of hammer to obtain the kidney shaped kernels. The kernels were divided into five portions: one potion was kept as a whole kernel (control), second portion was soaked in distilled water, third portion was autoclaved, fourth portion was roasted and the last portion was germinated.

\section{Soaking}

Cashew kernels $(50 \mathrm{~g})$ were soaked in tap water in a ratio $1: 10(\mathrm{w} / \mathrm{v})$ at room temperature $(25 \pm 2$ ${ }^{\circ} \mathrm{C}$ ) for 6,12 and $18 \mathrm{~h}$ respectively. The soaked kernels were washed twice with water, followed by rinsing with distilled water and then dried in an oven at $60{ }^{\circ} \mathrm{C}$ to a constant weight, according to Kaur and C. Kapoor (1990). The dried samples were milled using Philips laboratory blender (HR2811 model), to produce flour and sieved using a $60 \mathrm{~mm}$ mesh. The flour obtained was packed in a glass container and stored in a refrigerator, maintained at $8^{\circ} \mathrm{C}$ prior to use.

\section{Autoclaving}

Cashew kernels (50g) were autoclaved for 5, 10 and 15 min respectively at $121{ }^{\circ} \mathrm{C}$, according to Kaur and C. Kapoor (1990). The autoclaved kernels were dried at $60{ }^{\circ} \mathrm{C}$ to a constant weight. The dried samples were milled into flour using Philips laboratory blender (HR2811 model), and sieved using a $60 \mathrm{~mm}$ mesh. The flour obtained was packed in a glass container and stored in a refrigerator, maintained at $8^{\circ} \mathrm{C}$ prior to use. 
Impact of processing on nutritional and functional properties of cashew flour $\mid 3$

\section{Germination}

Cashew kernels $(500 \mathrm{~g})$ were sorted manually for viable kernels. The selected kernels were planted in a basket containing wood sawdust as the medium/substrate for growth. The planted kernels were watered daily. The kernels were allowed to germinate at $35 \pm 2{ }^{\circ} \mathrm{C}$ for 7 days producing radical protrusion of about $0.5 \mathrm{~cm}$. The germinated kernels were washed with distilled water, drained and dried in a hot air oven at $60{ }^{\circ} \mathrm{C}$, for $24 \mathrm{~h}$, according to Ijarotimi, Oluwalana, and Ogunedojutimi (2012).The dried samples were milled into flour using Philips laboratory blender (HR2811 model), and sieved using a $60 \mathrm{~mm}$ mesh. The flour obtained was packed in a glass container and stored in a refrigerator, maintained at $8{ }^{\circ} \mathrm{C}$ prior to use.

\subsection{Chemical analyses}

\section{Determination of proximate composition}

Standard methods according to the AOAC (2005) were used to determine moisture (AOAC925.10), fat (AOAC-2003.05) by soxhlet extraction and ash (AOAC-923.03) by combustion. Protein (AOAC-960.52) content (Nx6.25) was determined by micro Kjeldahl method. Carbohydrate content was determined by difference. The energy value was estimated (kcal/g) by multiplying the percentage crude protein, crude lipid and carbohydrate by the recommended factor (2.44, 8.37 and 3.57 respectively) as described by Eknayake, Jansz, and Nair (1999). All analyses were carried out in triplicate.

\section{Determination of mineral concentration}

The method according to the AOAC (2005) was used for the determination of mineral content. Two grams of the pulverized sample was placed in a crucible and ignited in a muffle furnace at $550{ }^{\circ} \mathrm{C}$ for $12 \mathrm{~h}$. The resulting ash was dissolved in $10 \mathrm{~mL}$ of $10 \% \mathrm{HNO}_{3}$, and heated slowly for $20 \mathrm{~min}$. After heating, it was filtered and the filtrate used for the determination of mineral content. The mineral constituents $(\mathrm{Ca}, \mathrm{Mg}$,
Fe and $\mathrm{Zn}$ ) were analyzed separately, using an atomic absorption spectrophotometer (Hitachi Z6100, Tokyo, Japan).

\section{Determination of anti- nutritional compounds}

\section{Determination of phytate content}

The phytate content of the flours was determined using method described by Oladele, Osundahunsi, Yemisi, and Adebowale (2009).Two $(2 \mathrm{~g})$ grams of each finely ground flour sample was soaked in $20 \mathrm{~mL}$ of $0.2 \mathrm{~N} \mathrm{HCl}$ and filtered. After filtration, $0.5 \mathrm{~mL}$ of the filtrate was mixed with $1 \mathrm{~mL}$ ferric ammonium sulphate solution in a test tube, boiled for 30min in a water bath, cooled in ice for $15 \mathrm{~min}$, and centrifuged at 3000 $\mathrm{rpm}$ for $15 \mathrm{~min}$. One millilitre of the supernatant was mixed with $1.5 \mathrm{~mL}$ of 2,2-pyridine solution and the absorbance measured with a spectrophotometer at a wavelength of $519 \mathrm{~nm}$. The concentration of phytic acid was obtained by extrapolation from a standard curve using standard phytic acid solution.

\section{Determination of oxalate content}

The titration method described by Oladele et al. (2009) was used to determine the oxalate content. One gram of the sample was weighed in a $100 \mathrm{~mL}$ conical flask, $75 \mathrm{~mL} 3 \mathrm{~N} \mathrm{H}_{2} \mathrm{SO}_{4}$ was added and stirred intermittently with a magnetic stirrer for $1 \mathrm{~h}$. The contents were then filtered using Whatman No.1 filter paper. From the filtrate, a $25 \mathrm{mLaliquot}$ was taken and titrated, while maintained at a temperature of $80-90^{\circ} \mathrm{C}$, against $0.1 \mathrm{~N}$ $\mathrm{KMnO}_{4}$ solution until a faint pink colour persisted for at least $30 \mathrm{sec}$.

\section{Determination of tannin content}

Tannin content was determined by the method described by Mugabo, Afoakwa, Annor, and Rwubatse (2017). One gram of sample was dispersed in $10 \mathrm{~mL}$ distilled water and agitated. The dispersion was left to stand for $30 \mathrm{~min}$ at room temperature $\left(20 \pm 2{ }^{\circ} \mathrm{C}\right)$, then centrifuged. $2.5 \mathrm{~mL}$ of the supernatant (extract) was pipetted into a $50 \mathrm{~mL}$ volumetric flask. Similarly, 2.5 
4| Maria and Hannah

$\mathrm{mL}$ of standard tannic acid solution was pipetted into a separate $50 \mathrm{~mL}$ flask. One millilitre of Folin-Denis reagent was measured into each flask, followed by $2.5 \mathrm{~mL}$ of saturated $\mathrm{Na}_{2} \mathrm{CO}_{3}$ solution. The mixture was made up to mark in a $50 \mathrm{~mL}$ volumetric flask and incubated for $90 \mathrm{~min}$ at room temperature. The absorbance was measured at $250 \mathrm{~nm}$ with a spectrophotometer (Jenway model $6000)$.

\section{Determination of functional properties}

The loose and packed densities were determined using the method described by Ikpeme, Osuchukwu, and Oshiele (2010). Water and oil absorption properties of the cashew flour were determined following methods of Adebayo, Ogunsina, and Gbadamosi (2013) with slight modifications. A flour sample ( $1 \mathrm{~g}$ ) was mixed with $10 \mathrm{~mL}$ distilled water for water absorption and $10 \mathrm{~mL}$ of oil for oil absorption in a Philips laboratory blender (HR2811 model) at high speed for $30 \mathrm{sec}$. Samples were allowed to stand for $30 \mathrm{~min}$ at room temperature then centrifuged (Uniscope, England) at 2000rpm for $30 \mathrm{~min}$. The volume of supernatant in a graduated cylinder was noted. Density of water was taken to be $1 \mathrm{~g} / \mathrm{mL}$ and that of oil was determined to be $0.993 \mathrm{~g} / \mathrm{mL}$. Analysis was performed in triplicate.

\section{Mineral bioavailability determination}

The bioavailability of minerals (calcium and magnesium, iron and zinc) was calculated as reported by Woldegiorgis, Abate, Haki, and Ziegler (2015). The molar ratio between anti-nutrient and mineral was obtained after dividing the mole of anti-nutrient with the mole of mineral. The mole of phytic acid was calculated as the measured value of phytic acid divided by the molecular weight of phytic acid (660.8) whereas, the mole of mineral ( $\mathrm{Ca}$ or $\mathrm{Mg} \mathrm{Fe}$ or $\mathrm{Zn}$ ) was calculated as the measured value of the mineral divided by the individual mineral molecular weight (Fe: 55.8, Zn: 65.4, Ca: 40.0, Mg: 24.3).

\subsection{Statistical analysis}

Determinations were carried out in triplicates and the error reported as standard deviation of the mean. Analysis of Variance (ANOVA) was performed and the least significant differences were calculated with the SPSS software for windows (release 17.00; SPSS Inc., Chicago IL, USA). Significance was accepted at $\mathrm{p} \leq 0.05 \mathrm{lev-}$ els.

\section{$3 \quad$ Results and Discussions}

The compositions of raw and treated cashew flours are presented in Table 1. The moisture content the flour was in the range of $2.68 \pm 0.10$ to $4.78 \pm 0.08 \%$. Soaking of cashew kernel for $18 \mathrm{~h}$ (sample $\mathrm{S}_{3}$ ) resulted in highest value $(4.78 \pm 0.08 \%)$, while lowest moisture content $(2.68 \%)$ was exhibited in the cashew kernel flour roasted for $15 \mathrm{~min}$ (sample $\mathrm{R}_{3}$ ). The lowest value recorded in sample $R_{3}$ may be attributed to a greater moisture loss by evaporation during roasting. This result is in agreement with the findings of Vickers, Peck, Labuza, and Huang (2014) who reported that roasting processes decreased moisture content of almond kernels. The moisture content of roasted cashew flour was however lower than $5.90 \%$ reported by Ogungbenle and Afolayan (2015). The protein content of the control sample $(21.3 \pm 0.05 \%)$ and germinated sample $(22.21 \pm 0.54 \%)$ were significantly higher compared to soaked, autoclaved and roasted flours respectively. Roasting resulted in a decrease in protein content over time compared to raw cashew flour. This is by virtue of the Maillard reaction, which is an interaction between the carbonyl group of a reducing sugar and the free amino group from an amino acid or protein. Similarly, soaking (6-18h) and autoclaving (5-15 min) of cashew kernel resulted in lower protein values compared to raw kernel due leaching of soluble proteins into processing water. However, the observed significant increase in protein value of germinated cashew flour could be attributed to the liberation of bound proteins during germination. Earlier studies also reported that during germination, carbohydrates are mobilized to synthesize amino acids for the 
Impact of processing on nutritional and functional properties of cashew flour $\mid 5$

growing seedling (Ocheme \& Chinma, 2008). There was significance difference $(\mathrm{p} \leq 0.05)$ in the fat content of the flour samples. The highest value $(53.0 \pm 0.08 \%)$ was observed in sample $\mathrm{S}_{3}$ while the lowest value $(45.0 \pm 0.15 \%)$ was exhibited in the control (sample C). Fat content of cashew kernel flour in this study increased with all processing techniques applied. The higher value noted in soaked flours compared to raw flour is perhaps due to the fact that soaking initiated the cleavage of the protein-lipid or carbohydrate-lipid linkages thereby facilitating the easy extraction of the oil by the extracting solvent (Madigan, Martinko, Parker, et al., 1997). Similarly, the higher lipid content in roasted sample compared to the control could be explained by the fact that oil bodies and the endoplasmic network were largely destroyed, and the volume of extracellular pores enlarged during roasting (Grundy et al., 2015). The fat content presently reported for roasted cashew flour was higher than that reported by Ogungbenle and Afolayan (2015). However, it is important to note that lipid oxidation, a critical factor in limiting shelf life, may be controlled to a large extent by roasting of nuts. Non-enzymatic reactions facilitate the release of antioxidants though the formation of acrylamide has been observed only in almonds and only at excessive roasting temperatures (Perren \& Escher, 2013). Furthermore, in terms of its physical behaviour during mastication, roasted nuts were found to be more brittle and crunchy and produced more loose particles post chewing than raw nuts (Vickers et al., 2014).

The ash content of the flour samples ranged from $1.59 \pm 0.15$ to $2.66 \pm 0.05 \%$, with the lowest value observed in the control sample. The significant increase in ash content of roasted samples compared to raw sample may be attributed to concentration of the organic compounds in the former during roasting. Soaking and autoclaving of cashew kernels with time also improved the ash content. The increase in ash content observed in soaked kernels could be attributed to leaching of some constituents, notably anti-nutrients into the processing water which in turn improved mineral availability. Similarly, higher ash content is expected especially at above ambient temperature employed during autoclaving through the swollen and ruptured cell walls which permeate water and soluble constituents. Germination process also improves the ash content of cashew flour. The fibre content of the flour samples ranged from $2.53 \pm 0.02$ to $5.76 \pm 0.12 \%$, with the lowest value observed in the control sample. The carbohydrate content of flour samples ranged from $15.8 \pm 0.16$ to $26.1 \pm 0.01 \%$. Carbohydrate has the highest composition by percentage in raw kernel flour (control) with a value of $26.1 \pm 0.01 \%$. The lower range recorded for soaked and autoclaved samples respectively, may be due to leaching of soluble carbohydrate (i.e. sugars) into the processing water. Similarly, the decrease in carbohydrate content of the roasted cashew kernel with time could be due to Maillard reaction, which occurred between amino acids, amines, aldehydes and carbonyl group of reducing sugars at high temperature to produce the roasted cashew flavour. The decreased carbohydrate content in germinated cashew flour (sample G) could be explained by the fact that hydrolysis of carbohydrate to sugar occurs during germination. The energy content of treated cashew samples was significantly different to that of the control sample. Energy value of the germinated flour was significantly $(\mathrm{p} \leq 0.05)$ lower than that of other flour samples. Generally, long-term consumption of nuts is associated with a decreased risk of weight gain and obesity (Bes-Rastrollo et al., 2009). Flores-Mateo, Rojas-Rueda, Basora, Ros, and Salas-Salvado (2013), in recent studies, observed no association between nut consumption and weight gain as demonstrated in a meta-analysis of clinical trials. Additionally, it is quite important to note that there was spontaneous reduction of energy intake subsequent to nut consumption, relative to a no-load or alternate load condition. That is, the majority, probably $65-75 \%$, of the energy reportedly provided by nuts is offset by lower energy intake at later eating events. Surprisingly, no single component of nuts appears responsible for this effect. The fatty acid profile is often mentioned but it does not appear to be responsible for spontaneous reduction of energy intake, because dietary compensation to walnuts, almonds, and peanut is comparable and they vary markedly in pro-

IJFS | April 2019 | Volume 8 $\mid$ pages 1-13 
6 | Maria and Hannah

Table 1: Proximate composition of cashew flours

\begin{tabular}{|c|c|c|c|c|c|c|c|}
\hline Sample & $\begin{array}{c}\text { Moisture } \\
(\%)\end{array}$ & $\begin{array}{l}\text { Protein } \\
(\%)\end{array}$ & $\begin{array}{l}\text { Fat } \\
(\%)\end{array}$ & $\begin{array}{c}\text { Fiber } \\
(\%)\end{array}$ & $\begin{array}{l}\text { Ash } \\
(\%)\end{array}$ & $\begin{array}{c}\text { Carbohydrate } \\
(\%)\end{array}$ & $\begin{array}{c}\text { Energy } \\
\text { (Kcal/g) }\end{array}$ \\
\hline $\mathrm{A}_{1}$ & $3.80^{e} \pm 0.10$ & $19.69^{e f} \pm 0.03$ & $45.16^{b} \pm 0.02$ & $3.85^{f} \pm 0.10$ & $2.44^{e} \pm 0.04$ & $22.05^{d} \pm 0.11$ & $515.50^{b}$ \\
\hline $\mathrm{A}_{2}$ & $3.94^{f} \pm 0.10$ & $19.63^{e} \pm 0.10$ & $47.51^{e} \pm 0.10$ & $3.76^{d} \pm 0.10$ & $2.51^{f} \pm 0.10$ & $22.63^{e} \pm 0.10$ & $526.34^{d}$ \\
\hline $\mathrm{A}_{3}$ & $3.99^{f g} \pm 0.06$ & $19.42^{d} \pm 0.03$ & $48.25^{g} \pm 0.71$ & $3.01^{b} \pm 0.03$ & $2.56^{g} \pm 0.06$ & $22.77^{f d} \pm 0.03$ & $526.98^{f}$ \\
\hline $\mathrm{S}_{1}$ & $4.61^{h} \pm 0.02$ & $21.11^{i} \pm 0.04$ & $51.06^{i} \pm 0.11$ & $3.82^{e} \pm 0.05$ & $1.67^{b} \pm 0.04$ & $16.76^{c} \pm 0.99$ & $542.18^{i}$ \\
\hline $\mathrm{S}_{2}$ & $4.69^{i} \pm 0.10$ & $20.57^{g} \pm 0.10$ & $52.81^{j} \pm 0.10$ & $3.77^{d} \pm 0.10$ & $1.76^{c} \pm 0.10$ & $16.40^{b} \pm 0.10$ & $550.76^{j}$ \\
\hline $\mathrm{S}_{3}$ & $4.78^{j} \pm 0.08$ & $20.93^{h} \pm 0.87$ & $53.00^{k} \pm 0.08$ & $3.63^{c} \pm 0.05$ & $1.87^{d} \pm 0.04$ & $15.97^{a} \pm 0.16$ & $551.05^{k}$ \\
\hline $\mathrm{R}_{1}$ & $3.04^{c} \pm 0.04$ & $19.13^{c} \pm 0.02$ & $45.29^{c} \pm 0.04$ & $5.76^{i} \pm 0.12$ & $2.47^{e f} \pm 0.03$ & $24.43^{i} \pm 0.14$ & $530.97^{g}$ \\
\hline $\mathrm{R}_{2}$ & $2.79^{b} \pm 0.10$ & $17.95^{b} \pm 0.10$ & $47.66^{f} \pm 0.10$ & $5.52^{h} \pm 0.10$ & $2.54^{f g} \pm 0.10$ & $23.54^{h} \pm 0.10$ & $526.75^{e}$ \\
\hline $\mathrm{R}_{3}$ & $3.04^{c} \pm 0.04$ & $17.73^{a} \pm 0.05$ & $48.87^{h} \pm 0.09$ & $5.18^{g} \pm 0.02$ & $2.66^{h} \pm 0.05$ & $22.91^{g} \pm 0.18$ & $533.98^{h}$ \\
\hline $\mathrm{G}$ & $2.79^{b} \pm 0.10$ & $22.21^{j} \pm 0.54$ & $45.68^{d} \pm 0.16$ & $3.80^{e} \pm 0.02$ & $2.72^{i} \pm 0.03$ & $22.02^{d} \pm 0.02$ & $512.00^{a}$ \\
\hline $\mathrm{C}$ & $2.68^{a} \pm 0.08$ & $21.25^{j} \pm 0.05$ & $45.03^{a} \pm 0.15$ & $2.53^{a} \pm 0.02$ & $1.59^{a} \pm 0.02$ & $26.14^{j} \pm 0.01$ & $521.75^{c}$ \\
\hline
\end{tabular}

portions of monounsaturated fatty acids and PUFA (USDA, 2002).

The mineral concentrations of raw and treated cashew flours are presented in Table 2. In parallel, with the observed increase in ash content in treated kernels, there was increase in mineral levels relative to the raw cashew flour. The highest concentration of mineral elements was noted in germinated samples followed by roasting, autoclaving and soaking. The enhancement of mineral concentrations during germination may be due to decomposition of anti-nutrient (notably phytate), thus releasing the bound nutrients. This result agrees with the report of Ihemeje, Ukauwa, and Ekwe (2015) who reported higher mineral concentrations in germinated walnut compared to raw walnut, though there was depletion as the germination time increased. The only factor that could account for higher mineral concentrations in roasted samples is the observed decrease in level of anti-nutrients. Similarly, soaked and autoclaved samples had higher mineral concentrations than the raw sample.

The anti-nutritional factors in the raw and treated flour samples are presented in Table 3 . The phytate, oxalate and tannin contents of raw and treated cashew kernel flours were found to be in a range of $50.27 \pm 0.03$ to $99.33 \pm 0.03 \mathrm{mg} / \mathrm{kg}$,
$4.62 \pm 0.03$ to $11.03 \pm 0.02 \mathrm{mg} / \mathrm{kg}$ and $4.47 \pm 0.04$ to $10.14 \pm 0.03 \mathrm{mg} / \mathrm{kg}$ respectively. Generally, flour samples from soaked, germinated, autoclaved and roasted cashew kernels produced significantly lower phytate, oxalate and tannin concentrations that were typical of products that had received some degree of treatment during preparation. However, the anti-nutritional factors were better deactivated by germination, roasting and autoclaving compared to soaking of the kernels. Furthermore, when the impact of different heat treatment (roasting and autoclaving) was compared to germination, germination was found to be more efficient in terms of deactivation of anti-nutrients as shown in Table 3. Water uptake of dry dehiscent nuts causes a rise in general metabolic activity and the formation of a seedling from the embryo during germination. Such growth requires phosphorus that is mobilized from the main storage form i.e. phytic acid and the process is accompanied with increase in phytase activity. The lower phytate and oxalate concentrations observed in roasted and autoclaved samples respectively may be attributed to the fact that they are heat labile. Similarly, observed decrease in anti-nutrients in soaked samples could be attributed to losses due to leaching during soaking and rinsing of the kernels. 
Impact of processing on nutritional and functional properties of cashew flour $\mid 7$

Table 2: Mineral concentrations of cashew flours $(\mathrm{mg} / \mathrm{kg})$

\begin{tabular}{lcccc}
\hline Sample & Calcium & Magnesium & Iron & Zinc \\
\hline $\mathrm{A}_{1}$ & $3312.00^{f} \pm 0.03$ & $1904.67^{e} \pm 0.03$ & $69.83^{e} \pm 0.02$ & $64.97^{c} \pm 0.04$ \\
$\mathrm{~A}_{2}$ & $3445.11^{g} \pm 0.03$ & $1963.23^{g} \pm 0.03$ & $70.97^{h} \pm 0.03$ & $68.54^{d} \pm 0.03$ \\
$\mathrm{~A}_{3}$ & $3553.02^{i} \pm 0.04$ & $1997.53^{i} \pm 0.03$ & $72.05^{i} \pm 0.03$ & $72.57^{i} \pm 0.03$ \\
$\mathrm{~S}_{1}$ & $2231.24^{b} \pm 0.05$ & $1869.42^{b} \pm 0.03$ & $67.39^{c} \pm 0.03$ & $63.09^{b} \pm 0.02$ \\
$\mathrm{~S}_{2}$ & $2257.43^{c} \pm 0.03$ & $1884.31^{c} \pm 0.03$ & $68.12^{d} \pm 0.03$ & $68.79^{e} \pm 0.03$ \\
$\mathrm{~S}_{3}$ & $2289.67^{d} \pm 0.03$ & $1892.33^{d} \pm 0.03$ & $69.98^{f} \pm 0.15$ & $70.60^{g} \pm 0.03$ \\
$\mathrm{R}_{1}$ & $3240.33^{e} \pm 0.05$ & $1929.42^{f} \pm 0.03$ & $65.32^{b} \pm 0.04$ & $69.76^{f} \pm 0.02$ \\
$\mathrm{R}_{2}$ & $3465.44^{h} \pm 0.03$ & $1987.48^{h} \pm 0.03$ & $70.23^{g} \pm 0.03$ & $72.33^{h} \pm 0.03$ \\
$\mathrm{R}_{3}$ & $3585.27^{j} \pm 0.05$ & $2060.33^{j} \pm 0.04$ & $75.12^{j} \pm 0.05$ & $77.95^{k} \pm 0.05$ \\
$\mathrm{G}$ & $3664.42^{k} \pm 0.03$ & $2118.05^{k} \pm 0.02$ & $79.22^{k} \pm 0.03$ & $75.96^{j} \pm 0.03$ \\
$\mathrm{C}$ & $2210.09^{a} \pm 0.02$ & $1712.54^{a} \pm 0.03$ & $60.04^{a} \pm 0.01$ & $36.74^{a} \pm 0.02$ \\
\hline
\end{tabular}

Data are mean values of triplicate determination \pm standard deviation.

Means within a row with different superscript are significantly different $(p \leq 0.05)$.

Table 3: Anti-nutrients content of cashew flours $(\mathrm{mg} / \mathrm{kg})$

\begin{tabular}{lccc}
\hline Sample & Phytate & Oxalate & Tannin \\
\hline $\mathrm{A}_{1}$ & $69.41^{i} \pm 0.02$ & $7.12^{h} \pm 0.02$ & $6.48^{f} \pm 0.06$ \\
$\mathrm{~A}_{2}$ & $57.12^{e} \pm 0.02$ & $6.93^{g} \pm 0.02$ & $6.23^{e} \pm 0.02$ \\
$\mathrm{~A}_{3}$ & $53.94^{b} \pm 0.04$ & $6.60^{f} \pm 0.04$ & $6.09^{d} \pm 0.02$ \\
$\mathrm{~S}_{1}$ & $65.86^{h} \pm 0.05$ & $9.24^{j} \pm 0.03$ & $7.14^{i} \pm 0.02$ \\
$\mathrm{~S}_{2}$ & $59.26^{f} \pm 0.02$ & $7.54^{i} \pm 0.02$ & $6.94^{f} \pm 0.02$ \\
$\mathrm{~S}_{3}$ & $55.92^{d} \pm 0.03$ & $6.16^{c} \pm 0.05$ & $6.73^{g} \pm 0.03$ \\
$\mathrm{R}_{1}$ & $70.43^{j} \pm 0.02$ & $6.20^{d} \pm 0.04$ & $6.48^{f} \pm 0.03$ \\
$\mathrm{R}_{2}$ & $62.54^{g} \pm 0.02$ & $5.13^{b} \pm 0.02$ & $6.03^{c} \pm 0.02$ \\
$\mathrm{R}_{3}$ & $50.27^{a} \pm 0.02$ & $4.62^{a} \pm 0.03$ & $5.73^{b} \pm 0.05$ \\
$\mathrm{G}$ & $55.61^{c} \pm 0.03$ & $6.38^{e} \pm 0.03$ & $4.47^{a} \pm 0.04$ \\
$\mathrm{C}$ & $99.33^{k} \pm 0.03$ & $11.03^{k} \pm 0.02$ & $10.14^{j} \pm 0.03$ \\
\hline
\end{tabular}

Data are mean values of triplicate determination \pm standard deviation.

Means within a row with different superscript are significantly different $(\mathrm{p} \leq 0.05)$. 
The presence of anti-nutrients in human diets affects nutrient absorption in infants and adults. Phytate chelates metal ions such as calcium, magnesium, zinc, copper and iron to form insoluble complexes that are not readily absorbed from the gastrointestinal tract. Its effect on mineral elements, especially in the case of iron is intense as even small amounts of phytic acid inhibit iron absorption in biological systems (Hurrell et al., 1992). Iron occurs in two forms in foods, as haem and as non-haem iron. Haem iron, which is present as haemoglobin and myoglobin, is absorbed directly as the intact iron porphyrin complex. Haem iron is well-absorbed (15-35\%) and little influenced by physiological or dietary factors. The absorption of non-haem iron varies widely and is influenced by dietary components and iron status of the individual (Monsen et al., 1978). In essence, different methods to reduce phytic acid during food preparation will have a positive effect on iron absorption. However, it is important to note that ascorbic acid has been shown to increase iron absorption and to at least partly overcome the inhibiting effect of phytic acid (Hallberg, Brune, \& Rossander, 1989). The mechanism of this effect is thought to be due to the prevention of the formation of insoluble iron compounds not available for absorption, and due to the reduction of ferric to ferrous iron (Hallberg et al., 1989). Tannin has been implicated in the formation of complexes with protein and minerals thereby limiting their availability. The toxicity effects of the tannin may not be significant since the total acceptable tannic acid daily intake for a man is $560 \mathrm{mg}$ (Gemede \& Fekadu, 2014). Similarly, anti-nutritional activity of oxalates lies in their ability to form complexes with metals like calcium, zinc, magnesium and iron making them unavailable for absorption. However, it is imperative to note that the risk of calcium deficiency due to the consumption of oxalate-rich plants has been reported to be minimal as humans are able to efficiently use very low amounts of calcium in food (Reddy, Balakrishnan, \& Salunkhe, 1978). Moreso, the concentrations of oxalate reported in this study are unlikely to pose toxicity problems to man since it is below the toxic levels of $2-5 \mathrm{~g}$ (Oke, 1969). Generally, the amount of anti-nutrients in nuts is highly variable; the levels found in a specific food probably depends on growing conditions, harvesting techniques, processing methods, testing methods and even the age of the food being tested (Bello, Salami-Jaji, Sani, Abdulhamid, \& Fakai, 2013).

The mineral bioavailability of raw and treated flours is presented in Table 4. Phytic acid has six strongly dissociated protons (pKn 1.1-2.9) and six weaker dissociated protons (pAa 4.6-12.0) as earlier reported by Cosgrove and Irving (1980). Phytate chelates metal ions to form insoluble complexes. Phytate works in a broad $\mathrm{pH}$-region (2.0-12.0) as reported by De Carli, Rosso, Schnitzler, and Carneiro (2006). Therefore, at $\mathrm{pH}$ values that normally occur in foods and under physiological conditions ( $\mathrm{pH} 1$ to 10); phytic acid being negatively charged has the potential to bind cations or positively charged divalent and trivalent mineral ions such as $\mathrm{Zn}^{2+}$, $\mathrm{Fe}^{2+/ 3+}, \mathrm{Ca}^{2+}, \mathrm{Mg}^{2+}, \mathrm{Mn}^{2+}$ and $\mathrm{Cu}^{2+}$ (Fredlund, Isaksson, Rossander-Hulthen, Almgren, \& Sandberg, 2006). The $\mathrm{pH}$ is also an important factor influencing the solubility of phytate, it being more soluble at lower than at higher pH values (Torre, Rodriguez, \& Saura-Calixto, 1991). The molar ratio of phytate to iron, calcium, magnesium and zinc were reduced when treatments (soaking, autoclaving, roasting and germination) were applied. The molar ratio of phytate to zinc and calcium were far below the recommended maximum value 15 and 0.24 in all the flour samples indicating better bioavailability for absorption. Similarly, raw and treated cashew flours had phytate to iron ratio within the recommended value of less than 1 (Walingo, 2009). As with iron, zinc, and calcium, it is assumed that magnesium-phytic acid complexes are formed in the intestine, which are insoluble at a $\mathrm{pH}>6$ (Champagne, 1988) and thus are not absorbable. However, the stability of the magnesium-phytic acid complex is weaker than phytic acid complexes with iron, copper, and zinc (Vohra, Gray, \& Kratzer, 1965). Any significant effect, due to the reduction in the level of anti nutrients in these samples, should be expected in the bioavailability of mineral elements. Therefore, the reduction achieved for the anti-nutrient in treated samples when compared to raw sample could be directly 
Impact of processing on nutritional and functional properties of cashew flour $\mid 9$

Table 4: Mineral bioavailability of cashew flours

\begin{tabular}{lcccc}
\hline Sample & $\begin{array}{c}\text { Phytate: Fe } \\
\text { molar ratio }\end{array}$ & $\begin{array}{c}\text { Phytate: Ca } \\
\text { molar ratio }\end{array}$ & $\begin{array}{c}\text { Phytate: Mg } \\
\text { molar ratio }\end{array}$ & $\begin{array}{c}\text { Phytate: Zn } \\
\text { molar ratio }\end{array}$ \\
\hline $\mathrm{A}_{1}$ & $0.08^{a b} \pm 0.00$ & n.d & n.d & $0.12^{d} \pm 0.00$ \\
$\mathrm{~A}_{2}$ & $0.07^{a} \pm 0.00$ & n.d & n.d & $0.08^{a b} \pm 0.00$ \\
$\mathrm{~A}_{3}$ & $0.07^{a} \pm 0.00$ & n.d & n.d & $0.07^{a} \pm 0.00$ \\
$\mathrm{~S}_{1}$ & $0.08^{a b} \pm 0.00$ & n.d & n.d & $0.10^{c} \pm 0.00$ \\
$\mathrm{~S}_{2}$ & $0.07^{a} \pm 0.00$ & n.d & n.d & $0.08^{a b} \pm 0.00$ \\
$\mathrm{~S}_{3}$ & $0.06^{a} \pm 0.00$ & n.d & n.d & $0.08^{a b} \pm 0.00$ \\
$\mathrm{R}_{1}$ & $0.09^{b} \pm 0.00$ & n.d & n.d & $0.10^{c} \pm 0.00$ \\
$\mathrm{R}_{2}$ & $0.08^{a b} \pm 0.00$ & n.d & n.d & $0.09^{b} \pm 0.00$ \\
$\mathrm{R}_{3}$ & $0.06^{a} \pm 0.00$ & n.d & n.d & $0.06^{a} \pm 0.00$ \\
$\mathrm{G}$ & $0.06^{a} \pm \pm 0.00$ & n.d & n.d & $0.07^{a} \pm 0.00$ \\
$\mathrm{C}$ & $0.14^{c} \pm \pm 0.00$ & n.d & n.d & $0.27^{e} \pm 0.00$ \\
\hline
\end{tabular}

n.d - not detected.

Data are mean values of triplicate determination \pm standard deviation.

Means within a row with different superscript are significantly different $(\mathrm{p} \leq 0.05)$.

Table 5: Functional properties of cashew flours

\begin{tabular}{|c|c|c|c|c|}
\hline \multirow{2}{*}{ Sample } & \multicolumn{2}{|c|}{ Bulk density (g/mL) } & \multirow{2}{*}{$\begin{array}{c}\text { WAC } \\
(\mathrm{mL} / \mathbf{1 0 0 g})\end{array}$} & \multirow{2}{*}{$\begin{array}{c}\text { OAC } \\
(\mathrm{mL} / 100 \mathrm{~g})\end{array}$} \\
\hline & Loose & Packed & & \\
\hline $\mathrm{A}_{1}$ & $0.45^{b} \pm 0.01$ & $0.63^{d} \pm 0.01$ & $90.00^{b} \pm 0.15$ & $166.00^{e} \pm 0.17$ \\
\hline $\mathrm{A}_{2}$ & $0.45^{b} \pm 0.01$ & $0.60^{c} \pm 0.01$ & $94.00^{c} \pm 1.15$ & $182.00^{g} \pm 1.15$ \\
\hline $\mathrm{A}_{3}$ & $0.45^{b} \pm 0.02$ & $0.58^{b} \pm 0.01$ & $100.00^{d} \pm 0.45$ & $200.00^{h} \pm 0.28$ \\
\hline $\mathrm{S}_{1}$ & $0.45^{b} \pm 0.01$ & $0.55^{a} \pm 0.03$ & $96.00^{c d} \pm 0.17$ & $173.00^{f} \pm 0.14$ \\
\hline $\mathrm{S}_{2}$ & $0.44^{b} \pm 0.01$ & $0.55^{a} \pm 0.01$ & $102.00^{d} \pm 1.15$ & $207.00^{i} \pm 1.15$ \\
\hline $\mathrm{S}_{3}$ & $0.44^{b} \pm 0.03$ & $0.55^{a} \pm 0.02$ & $110.00^{e} \pm 0.14$ & $225.00^{j} \pm 0.21$ \\
\hline $\mathrm{R}_{1}$ & $0.49^{c} \pm 0.01$ & $0.57^{b} \pm 0.01$ & $90.00^{b} \pm 0.14$ & $137.00^{b} \pm 0.15$ \\
\hline $\mathrm{R}_{2}$ & $0.49^{c} \pm 0.01$ & $0.60^{c} \pm 0.01$ & $107.00^{e} \pm 1.15$ & $146.00^{c} \pm 1.15$ \\
\hline $\mathrm{R}_{3}$ & $0.53^{d} \pm 0.02$ & $0.66^{e} \pm 0.02$ & $110.00^{f} \pm 0.07$ & $150.00^{d} \pm 0.14$ \\
\hline G & $0.49^{c} \pm 0.01$ & $0.61^{c} \pm 0.02$ & $95.00^{c} \pm 0.35$ & $165.00^{e} \pm 0.21$ \\
\hline $\mathrm{C}$ & $0.40^{a} \pm 0.01$ & $0.65^{e} \pm 0.01$ & $87.00^{a} \pm 0.11$ & $130.00^{a} \pm 0.12$ \\
\hline
\end{tabular}

WAC-Water absorption capacity; OAC- Oil absorption capacity.

Data are mean values of triplicate determination \pm standard deviation.

Means within a row with different superscript are significantly different $(p \leq 0.05)$.

IJFS | April 2019 | Volume 8 | pages 1-13 
related to this improved availability. In essence, bioavailability of nutrients in processed food products could be enhanced when they contain minimal amount of residual anti nutritional factors. This is of great concern in Community Nutrition and Emergency Feeding Programmes in developing countries where the consequence of anti-nutritional factors may worsen incidence of malnutrition and disease among infants and other vulnerable groups.

The functional properties of raw and treated flours are as shown in Table 5. Determination of functional properties of food ingredient is essential for the development of different food products especially for children. Processing methods had significant effect $(\mathrm{p} \leq 0.05)$ on the functional parameters under consideration. The loosed bulk density value ranged from $0.44 \pm 0.01$ to $\quad 0.53 \pm 0.02 \mathrm{~g} / \mathrm{mL}$. Roasting significantly $(\mathrm{P} \leq 0.05)$ increased the loosed bulk density of cashew flour. Sample $\mathrm{R}_{3}$ had the maximum value, while the control sample had the least. The increase in loose density of the flour sample as a result of soaking and germination could be attributed to enzymatic activities. The packed bulk densities of the flour samples ranged from $0.55 \pm 0.01$ to $0.66 \pm 0.02 \mathrm{~g} / \mathrm{mL}$. The reduction in packed density observed in germinated sample might have been as a result of decrease in weight of the flour owing to the breakdown of complex denser compounds inherent in cashew kernel into simpler ones (Gernah, Ariahu, \& Ingbian, 2011). Similarly, Ihemeje et al. (2015), in earlier studies, observed a reduction in bulk density of germinated walnut compared to raw sample. The decrease in packed density of the flour sample, as a result of soaking, could also be attributed to enzymatic activities. The high volume per gram of flour material is important in relation to its packaging. It is desirable to have high bulk density in that it offers greater packaging advantage, as greater quantity may be packed within a constant volume (Adepeju, Gbadamosi, Adeniran, \& Omobuwajo, 2011). Moreso, higher bulk density is important factor in convalescent child feeding.

Water absorption capacity (WAC) of flour samples ranged from $87.0 \pm 0.11$ to $110.0 \pm 0.14 \mathrm{~mL} / 100 \mathrm{~g}$. Water absorption capacity of food product is an index of the maximum amount of water the product absorbs and retains and it is important to soften and increase digestibility (Ijarotimi et al., 2012). Differences in WAC of raw and treated flour samples could be, as a result of differences in the content of polar amino acid residues of proteins or charged side chains, which have an affinity for water molecules (Jitngarmkusol, Hongsuwankul, \& Tananuwong, 2008). The oil absorption capacities (OAC) of cashew flours were in the range of $130.0 \pm 0.12$ to $225.0 \pm 0.21 \mathrm{~mL} / 100 \mathrm{~g}$. The oil absorption capacity values were generally higher than those of the water absorption capacity. Evidence on oil absorption of the samples indicate that there was significant $(\mathrm{p} \leq 0.5)$ difference in the values obtained in raw and treated samples. Autoclaving and roasting significantly increased the oil absorption compared to the control. The increased oil absorption capacity of heat-processed samples may be due to the denaturation and dissociation of their constituent proteins that occur on heating which unmasks the non-polar residues from the interior of the protein molecule (Odoemelam, 2005). Similarly, germination improved the oil absorption capacity of cashew flour compared to the raw flour. The increase in oil absorption capacity of germinated sample may be attributed to the increased activity of lipolytic enzymes, which produce more free fatty acids during sprouting (Ihemeje et al., 2015).

\section{Conclusion}

The present study has demonstrated that processing of cashew kernel by soaking, roasting, germination or autoclaving had significant adjustments in the nutrient density and functional properties. Various processing methods significantly decreased the levels of phytate, oxalate and tannin with corresponding improvement in mineral bioavailability. Germination shows potential, to generate not only much needed nutrients in cashew for human, but also improved bioavailability of nutrients and functionality compared to other processing methods. 
Impact of processing on nutritional and functional properties of cashew flour $\mid 11$

\section{References}

Abebe, Y., Stoecker, B., Hinds, M., \& Gates, G. (2006). Nutritive value and sensory acceptability of corn- and kocho-based foods supplemented with legumes for infant feeding in southern ethiopia. African Journal of Food, Agriculture, Nutrition and Development, 6 .

Adebayo, W. A., Ogunsina, B. S., \& Gbadamosi, S. O. (2013). Some physico-chemical and functional properties of kariya (hildegardia baterii) kernel flours. Ife Journal of Science, 15(3), 477-488.

Adepeju, A. B., Gbadamosi, S., Adeniran, A., \& Omobuwajo, T. O. (2011). Functional and pasting characteristics of breadfruit (artocarpus altilis) flours. African Journal of Food Science, 5, 529-535.

AOAC. (2005). Association of Official Analytical Chemists. Official Methods of Analysis of the Association of Analytical Chemists International. Gathersburg, MD U.S.A Official methods, 2005.08.

Bello, F., Salami-Jaji, J., Sani, I., Abdulhamid, A., \& Fakai, I. M. (2013). Evaluation of some antinutritional factors in oil-free white sesamum indicum 1 . seed cake. International Journal of Food Nutrition and Safety, 4(1), 27-33.

Bes-Rastrollo, M., Wedick, N. M., MartinezGonzalez, M. A., Li, T. Y., Sampson, L., \& Hu, F. B. (2009). Prospective study of nut consumption, long-term weight change, and obesity risk in women. American Journal of Clinical Nutrition, 89(6), 1913-1919. doi:10.3945/ajcn.2008.27276

Champagne, E. T. (1988). Effects of $\mathrm{PH}$ on mineral phytate, protein mineral-phytate, and mineral fiber interactions-possible consequences of atrophic gastritis on mineral bioavailability from high-fiber foods. Journal of the American College of Nutrition, 7(6), 499-508.

Cosgrove, D. J., \& Irving, G. C. J. (1980). Inositol phosphates: Their chemistry, biochemistry, and physiology. Studies in organic chemistry. Elsevier Scientific Pub. Co. Retrieved from https: / / books.google.pt / books?id=C0k3AQAAIAAJ
De Carli, L., Rosso, N. D., Schnitzler, E., \& Carneiro, P. I. B. (2006). Estudo da estabilidade do complexo ãjcido fãtico e o ãon ni(ii). Food Science and Technology, 26, 1926. doi:10.1590/S0101-20612006000100004

Eknayake, S., Jansz, E. R., \& Nair, B. M. (1999). Proximate composition, mineral and amino acid content of mature canavalia gladiata seeds. Food Chemistry, 66(1), 115-119.

Esenwah, C. N., \& Ikenebomeh, M. J. (2008). Processing effects on the nutritional and anti-nutritional contents of african locust bean (parkia biglobosa benth.) seed. Pakistan Journal of Nutrition, 7(2), 214-217.

FAO. (2008). Agriculture, food and nutrition for africa. Rome, 385-387.

Flores-Mateo, G., Rojas-Rueda, D., Basora, J., Ros, E., \& Salas-Salvado, J. (2013). Nut intake and adiposity: Meta-analysis of clinical trials. American Journal of Clinical Nutrition, 97(6), 1346-1355. doi:10.3945/ ajcn.111.031484

Fredlund, K., Isaksson, M., Rossander-Hulthen, L., Almgren, A., \& Sandberg, A. S. (2006). Absorption of zinc and retention of calcium: Dose-dependent inhibition by phytate. Journal of Trace Elements in Medicine and Biology, 20(1), 49-57. doi:10. 1016/j.jtemb.2006.01.003

Gemede, H. F., \& Fekadu, H. (2014). Nutritional composition, antinutritional factors and effect of boiling on nutritional composition of anchote (coccinia abyssinica) tubers. Journal of Scientific and Innovative Research, 3(2), 177-188.

Gernah, D. I., Ariahu, C. C., \& Ingbian, E. K. (2011). Effects of malting and lactic fermentation on some chemical and functional properties of maize (zea mays). American Journal of food technology, 6 (5), 404-412.

Gibbon, D. P., \& Pain, A. (1985). Crops of the drier regions of the tropics. Intermediate tropical agriculture series. Longman. Retrieved from https:// books.google.pt/ books?id=K\%5C_4gAQAAMAAJ

Grundy, M. M. L., Grassby, T., Mandalari, G., Waldron, K. W., Butterworth, P. J., Berry, S. E. E., \& Ellis, P. R. (2015). Effect of mastication on lipid bioaccessibility of almonds in a randomized human study and its im-

IJFS | April 2019 | Volume 8 | pages 1-13 
plications for digestion kinetics, metabolizable energy, and postprandial lipemia. American Journal of Clinical Nutrition, 101(1), 25-33. doi:10 . 3945/ ajcn . 114 . 088328

Hallberg, L., Brune, M., \& Rossander, L. (1989). Elevated dosages of vitamins: Benefits and hazards. In H. S. P. W. Brubacher (Ed.), (pp. 103-108). International journal for vitamin and nutrition research: Supplement. Hans Huber Publishers. Retrieved from https : / / books . google . pt / books ? id = GRdrAAAAMAAJ

Hammed, L., Anikwe, J., \& Adedeji, R. (2008). Cashew nuts and production development in nigeria. American-Eurasian Journal of Scientific Research, 3(1).

Hurrell, R. F., Juillerat, M. A., Reddy, M., Lynch, S., Dassenko, S. A., \& Cook, J. D. (1992). Soy protein, phytate, and iron absorption in humans. The American journal of clinical nutrition, 56, 573-8.

Ihemeje, A., Ukauwa, O., \& Ekwe, C. (2015). Effects of cooking and germination on physiochemical properties and sensory attributes of african walnut (tetracarpidium conophorum). International Journal of Pharmacology, Phytochemistry and Ethnomedicine, 1, 93-102.

Ijarotimi, O. S., Oluwalana, I. B., \& Ogunedojutimi, M. O. (2012). Nutrient composition, functional, sensory and microbial status of popcorn-based complementary foods enriched with cashew nut flour. African Journal of Food, Agriculture, Nutrition and Development, 12(5), 684-5374.

Ikpeme, C. A., Osuchukwu, N., \& Oshiele, L. (2010). Functional and sensory properties of wheat (aestium triticium) and taro flour (colocasia esculenta) composite bread. African Journal of Food Science, $4(5), 248-253$.

Jitngarmkusol, S., Hongsuwankul, J., \& Tananuwong, K. (2008). Chemical compositions, functional properties, and microstructure of defatted macadamia flours. Food Chemistry, 110, 23-30.

Kaur, D., \& C. Kapoor, A. (1990). Starch and protein digestibility of rice bean (vigna umbellata): Effects of domestic processing and cooking methods. Food Chemistry, 38, 263272.

Madigan, M. T., Martinko, J. M., Parker, J., et al. (1997). Brock biology of microorganisms. Prentice hall Upper Saddle River, N. J.

Monsen, E. R., Hallberg, L., Layrisse, M., Hegsted, D. M., Cook, J. D., Mertz, W., \& Finch, C. A. (1978). Estimation of available dietary iron. The American journal of clinical nutrition, 31, 134-41.

Mugabo, E., Afoakwa, E. O., Annor, G., \& Rwubatse, B. (2017). Effect of pretreatments and processing conditions on antinutritional factors in climbing bean flours. International Journal of Food Studies, $6(1), 34-43$.

Ngatchic, J. T. M., Sokeng, S. D., Njintang, N. Y., Maoundombaye, T., Oben, J., \& Mbofung, C. M. F. (2013). Evaluation of some selected blood parameters and histopathology of liver and kidney of rats fed protein-substituted mucuna flour and derived protein rich product. Food and Chemical Toxicology, 57, 46-53. doi:10 . 1016/j.fct.2013.02.045

Ocheme, O., \& Chinma, C. (2008). Effects of soaking and germination on some physicochemical properties of millet flour for porridge production. Journal of Food Technology, 6(5), 185-188.

Odoemelam, S. A. (2005). Proximate composition and selected physicochemical properties of the seeds of african oil bean (Pentaclethra marcrophylla). Pakistan Journal of Nutrition, 4, 382-383.

Ogungbenle, H. N., \& Afolayan, M. F. (2015). Physical and chemical characterization of roasted cashew nut (anacardium occidentale) flour and oil. International Journal of Food Science and Nutrition Engineering, $5(1), 1-7$.

Oke, O. L. (1969). The role of hydrocyanic acid in nutrition. World Review of Nutrition and Dietetics, 11, 170-98.

Oladele, K. A., Osundahunsi, F. O., Yemisi, O. A., \& Adebowale, A. Y. (2009). Influence of processing techniques on the nutrient and antinutrient of tiger nut (cyperus esculentus 1.) World Journal of Dairy and Food Sciences, 4, 88-93. 
Impact of processing on nutritional and functional properties of cashew flour $\mid 13$

Perren, R., \& Escher, F. E. (2013). Improving the safety and quality of nuts. In L. J. Harris (Ed.), (Chap. Impact of roasting on nut quality, pp. 173-197). Woodhead Publishing Series in Food Science, Technology and Nutrition. Elsevier Science. Retrieved from https://books.google.pt/books?id= wlpEAgAAQBAJ

Reddy, N. R., Balakrishnan, C. V., \& Salunkhe, D. K. (1978). Phytate phosphorus and mineral changes during germination and cooking of black gram (phaseolus mungo) seeds. Journal of Food Science, 43(2), 540-543.

Sathe, S. (1994). Solubilization and electrophoretic characterization of cashew nut (anacardium occidentale) proteins. Food Chemistry, 51, 319-324.

Słupski, J. (2011). Evaluation of the effect of pretreatment and preservation on macroand microelements retention in flageolet (Phaseolus vulgaris 1.) bean seeds. Acta Scientiarum Polonorum. Technologia Alimentaria, 10(4), 475-485.

Torre, M., Rodriguez, A. R., \& Saura-Calixto, F. (1991). Effects of dietary fiber and phytic acid on mineral availability. Critical reviews in food science and nutrition, 30, 122.

USDA. (2002). United states department of agriculture, agricultural research service. national nutrient database for standard. Retrieved from http://www.nal.usda.gov / fnic/foodcomp

Vickers, Z., Peck, A., Labuza, T., \& Huang, G. (2014). Impact of almond form and moisture content on texture attributes and acceptability. Journal of Food Science, 79, 1399-1406.

Vohra, P., Gray, G. A., \& Kratzer, F. H. (1965). Phytic acid-metal complexes. Proceedings of the Society for Experimental Biology and Medicine, 120(2), 447-449.

Walingo, M. K. (2009). Indigenous food processing methods that improve zinc absorption and bioavailability of plant diets consumed by the kenyan population. African Journal of Food, Agriculture, Nutrition and Development, 9, 523-535.

Woldegiorgis, A. Z., Abate, D., Haki, G. D., \& Ziegler, G. R. (2015). Major, minor and toxic minerals and anti-nutrients composition in edible mushrooms collected from ethiopia. Food Processing Technology, 6, 134-142. 